\title{
Working With Husband? ‘Occupation's Wife’ And Married Women’s Employment in the Censuses in England and Wales Between 1851 And 1911
}

\begin{abstract}
$\underline{\text { Abstract }}$
Women played a vital role in British industrialization. However, studies of women's work are often hindered by data limitation. The British censuses provide an unparalleled opportunity to study women's work and its impact systematically. However, the reliability of the census recording of female employment is still under debate. This articles aims to contribute to this ongoing debate by examining a particular census recording concerning married women who were supposedly working with their husbands, i.e. 'occupation's wife'. By analyzing a new source of big data, namely 100 percent sample of Census Enumerators' Books and published census reports, this article shows that the recording of 'occupation's wife' was not informative about the level of married women's labour in the form of working together with their husbands in the same trade. Given the important fact that married women recorded as 'occupation's wife' constituted the largest group of married women with any occupational titles in the censuses, the results presented in this article suggest a re-assessment of some of the empirical foundations in the studies of married women's work.
\end{abstract}

Word count: 11,585 


\section{Main Text}

Women played a vital role during the British industrialization. Their cheap, diligent and flexible labour influenced the direction as well as the nature of the industrialization process (Honeyman 2000: 36). From the centralized cotton factories in Lancashire to the traditional putting-out workshops in the countryside, female labour was a key determinant in the success of industrial capitalism (Berg 1993; Hudson 1992; Lown 1990). In addition, women’s contribution to the economy did not just confine itself to the formal labour market. The monetary returns to their labour may have been relatively small in comparison with men (Horrell and Humphries 1995). Their non-monetary contributions in the form of childcare, gleaning, managing household budget and organizing credit nonetheless proved to be essential in many households’ wellbeing and survival (Humphries 1990; Lemire 2005; Sharpe 1996).

Given women's important contribution to the economy, an accurate assessment of female labour is needed to answer some of the most important questions in economic and social history such as economic productivity, real wages and organization of household economy. Admittedly, the limited data availability has often hindered historians' attempts to achieve such a goal. However, thanks to the digitization of the official statistics on women's occupations in the census from mid-nineteenth century onwards, there is now an unparalleled opportunity to systematically study women's work and its impact on the market and household economy. But a critical evaluation of the empirical basis should always be undertaken before the making of major arguments. It is the aim of this article to contribute to the ongoing debate with regard to the quality of the information on female employment in the British census.

Ever since the publication of Edward Higgs' article (1987) drawing attention to the potential pitfalls of using British census statistics, the literature has never been short of criticisms of the accuracy of the census recording of women’s employment (Bourke 1994: 167; Burnette 2008; 
Davidoff and Hall 1987: 27; Hill 1993; Horrell and Humphries 1995: 95; Roberts 1995: 18-9; Sharpe 1995: 333; Verdon 1999). More recently, studies undertaken by Michael Anderson (2007, 2007), Leigh Shaw-Taylor (2007), Timothy Hatton and Roy Bailey (2001), Sophie McGeevor (2014), as well as Higgs and Wilkinson (2016) launched a powerful counterargument to most of the criticisms and to some extent restored our faith in the census recording. However, even those optimists admit, due to married women's general economic dependence on male wages and the irregular nature of their employment, census reporting of married women’s employment was most problematic (Shaw-Taylor 2007).

So far the focus on married women's employment in the census has been its under-reporting. While this criticism is true in many case studies, it is certainly not the whole story. It is fair to argue that the most notable problem of using the census to study women's employment is not its alleged inaccuracy. It is the fact that we still have not obtained a full picture of what exactly the nature and the scale of the problems are. As Higgs argues 'It is clear, therefore, that there is a considerable body of opinion that holds that the censuses under-enumerated the work of women during the Victorian era. What is less clear, however, is where the factual evidence for this conclusion with respect to the British censuses, at least in terms of occupational titles, is to be found' (Higgs and Wilkinson 2016: 18-9). With criticism misplaced and attention mistargeted, any future effort to provide a reasonably accurate account of women's work and its impact on the market and household economy would be in vain.

This article will enrich our understanding of the census recording of women's employment by examining a particular issue pertaining to married women's work. That is the enumeration of 'occupation's wife' in the Census Enumerators' Books (hereafter CEBs) as well as the tabulation of 'occupation's wife' in the published census reports. This peculiar term as a description of married women's occupations in the census deserves some terminological explanations. The occupation within the single quote refers to husband's occupation. It could 
be farmer, butcher, agriculture labourer etc. The occupational title for married women in concern then were farmer's wife, butcher's wife and agriculture labourer's wife etc. Unlike more conventional occupational titles such as 'spinner' or 'domestic servant', the term 'occupation's wife' is embedded with conceptual ambiguity. Ascertaining which aspects of married women's labour 'occupation's wife' tried to capture is one of the main objectives of this article.

There are only few existing studies of 'occupation's wife' and they have so far only focused on the inconsistent tabulation of 'occupation's wife' in the published census reports over time. It has been revealed that wives of farmers, shoemakers, butchers, shopkeepers and innkeepers were considered by the census officials between 1851 and 1871 to be working together with their husband in the same trade. Hence, they were included in the employment totals in the published census reports. But from 1881 onwards, they were assumed to be unoccupied. Based on this finding, Booth, Higgs and McKay have all discussed its distortive effect on constructing a reliable series of women's labour force participation rate (hereafter LFPR) over time (Booth 1886; Higgs 1987; McKay 2007). Female LFPR from 1881 onwards, calculated from the census materials, was particularly underestimated. More recently, Humphries in her Ellen McArthur lectures uses 'occupation's wife' in the census as an example of married women gaining access to the labour market by the dint of their husband's employment (Humphries 2016). She argues that, contrary to the belief that marriage limited women's labour force participation, it enabled women's employment in certain occupations. The aforementioned arguments are all based on the crucial assumption that 'occupation's wife' in the census indeed captured married women's labour in the form of working together with their husband in the same trade. However, there has been no discussion on the validity of this assumption in the literature. 
As will be demonstrated later in this article, women recorded as 'occupation's wife' constitute the largest group of married women with any occupational titles in the census. Therefore, to ascertain whether 'occupation's wife' captured married women's work with their husband is not just an issue of technicality concerning the mechanism of census recording. It has a profound effect on solidifying the empirical basis for future studies of married women's labour force participation. Two major findings will emerge from this article. First, 'occupation's wife' in the census does not reveal much about the true level of married women's labour in the form of working together with their husband in the same trade. Second, the recording of 'occupation's wife' does reveal certain aspects of the gender relationship in the nineteenth century, particularly how the male adherence to domestic ideologies magnified women's supposed domestic position as someone's wife and ignored their economic function as wage earner and family business partner. However, it should be stressed at this point that it is not the author's intention to discredit census materials as an invaluable source to study women's employment in the nineteenth century. By identifying and discussing a problem that has so far been missing from the literature, the author only aims to enrich our understanding of the census and to facilitate future research using such material.

This article will be organized as follows. Section I will briefly discuss the source materials, namely the Integrated Census Microdata (hereafter I-CeM) dataset of the CEBs and the published census reports in England and Wales between 1851 and 1911. Section II will analyze the tabulation of 'occupation's wife' in the published census reports. Patterns of the enumeration of 'occupation's wife' in the CEBs will be presented in section III. Section IV aim to find the rationale behind the enumeration of 'occupation's wife in the CEBs. Section V will use 'farmer's wife' in the 1881 CEBs as a particular example to further the argument. Some caveats and conclusion will be presented in sections VI and VII.

\section{I: Source Materials}


This article uses two related, and yet not completely synonymous, bodies of census materials: the 100 percent sample of CEBs in England and Wales between 1851 and 1911 (with the exception of 1871) and the published census reports in England and Wales between 1851 and 1911. The biggest difference between the CEBs and the published census report is that the former contain nominal data at the individual level while the latter only contain tabulations grouped by sex, age and various geographical units based on the information recorded in the CEBs. The British censuses started recording female occupations from 1841, but it was not until 1851 that it started to be fit for analytical purposes (Higgs 1987: 63). Although the exact enumeration procedures may have varied slightly across different census years since 1851, the core procedures by which the censuses were taken were similar (Higgs 2005; Mills and Schürer 1996).

There were more than 600 registration districts in England and Wales in the mid-nineteenth century. Each of them was under the charge of a superintendent registrar. These registration districts were further divided into sub-districts, each under the charge of a registrar. Registrars were instructed to divide their sub-districts into Enumeration Districts (hereafter EDs). EDs were the geographical basis in which the census enumeration took place, and each ED was in the charge of a census enumerator. However, it should be noted that Enumeration Districts often do not coincide with parishes. ${ }^{1}$ EDs were supposed to be of fairly standard size either in terms of population or geography (Higgs 2005: 37-8). Census enumerators distributed the household schedules to householders over the previous week before the census night. Information requested in the household schedules were the address of the household, as well

\footnotetext{
${ }^{1}$ Higgs, Making sense of the census, pp. 37-38. For example, while there were c. 15,000 parishes in England and Wales in 1861, there were c. 30,000 Enumeration Districts in England and Wales in 1861.
} 
as the name, relationship to household head, marital status, sex, age, 'Rank, profession or occupation', birth place, and description of medical disability for each person residing in it on the census night as well as those returning to the household in the morning. The occupational recording under the 'Rank, profession or occupation' column are the core information this article relies on. With regard to filling this column, there were a set of instructions that householders were supposed to follow. Census enumerators then transferred the information from household schedules to their CEBs with certain revisions and checks, according to the instructions given to them, in the morning after the census night. The CEBs were then sent to the local registrars and superintendent registrars. At each stage examinations, checks and simple tabulations were performed (Woollard 1998). Then the CEBs, household schedules and various summary forms were sent to the Census Office in London. Here, some 60 clerks, with a set of instructions given to them, spent around three months undertaking further checks on the CEBs and performing the tabulations which led to various tables in the published census reports. It is clear that the CEBs were regarded by the census authorities only as the medium by which the end product, namely the published reports were to be obtained. The editorial interference - such as revisions, checks and standardization - carried out during each stage before the finalization of the published census reports could add further alterations to the enumerators' initial recordings in the CEBs (Woollard 1998). The only notable exception to the aforementioned procedures occurred in 1911 when the original household schedules rather than the CEBs formed the basis for the tabulation in the published census reports.

The sheer volume of data contained in the CEBs and published census reports constitutes an analytical obstacle. For example, the 1851 CEBs in England and Wales contain c. 18 million individual records; the 1911 CEBs in England and Wales contain c. 36 million individual records. Without them available in a machine-readable form, it would be impossible to conduct detailed research so that their full potential could be realized. Fortunately, the digitization is 
done now. The I-CeM project ${ }^{2}$ led by Schürer and Higgs, with the raw data supplied by their commercial partner FindMyPast, created a digitized and standardized dataset of all the CEBs between 1851 and 1911, with the only exception being $1871 .{ }^{3}$ In this dataset, they reformatted the input data, performed a number of consistency checks, coded the non-standard textual occupational strings with the occupational classification, and added a number of enriched variables relating to household structure. ${ }^{4}$ Shaw-Taylor, Reid and Bennett et al at the Cambridge Group for the History of Population and Social Structure (hereafter Campop) undertook further checks and corrections to the I-CeM dataset and linked the dataset to the Geographic Information System (hereafter GIS) boundary data so that cartographical representation could be produced. ${ }^{5}$ The published census reports were digitized by Campop as part of the Occupation Project led by Shaw-Taylor and Wrigley. ${ }^{6}$ The dataset of published

\footnotetext{
${ }^{2}$ Schürer and Higgs, Integrated Census Microdata (I-CeM), 1851-1911.

${ }^{3}$ The digitization of the full sample of 1871 CEBs was not yet available when I-CeM datasets were launched.

${ }^{4}$ Higgs, Jones and Schürer et al. ‘Integrated Census Microdata (I-CeM) Guide’.

${ }^{5}$ The GIS parish boundary data used in this article is Satchell, Kitson and Newton et al. 1851 England and Wales census parishes, townships and places. It is an extensively corrected, extended and enhanced version of Burton and Southall, GIS of the ancient parishes of
} England and Wales, 1500-1850. It is in turn is a GIS version of Kain and Oliver, Historic Parishes of England and Wales : an Electronic Map of Boundaries before 1850 with a Gazetteer and Metadata.

6 'Occupational Structure of Britain c.1371-1911'. For the full list of funding bodies, see www.campop.geog.cam.ac.uk/research/occupations/acknowledgements/funding/ (accessed June 1) 
census reports was also linked to GIS boundary data. Furthermore, this article will also utilize the farm acreage information that Gill Newton extracted from the 1881 CEBs as part of the Entrepreneurship Project led by Bennett at Campop. ${ }^{7}$

\section{II: 'Occupation’s Wife’ in Published Census Reports}

The tabulation of 'occupation's wife' was inconsistent over time in the published census reports. Prior to 1881, wives of farmers, shoemakers, butchers, shopkeepers, and innkeepers were assumed to be working together with their husband in the same trade. Hence, they were included in the employment totals in the published census reports. For instance, one item in the instructions to the census clerks employed in producing the published census reports in 1871 reads:

The WIVES of the following Persons are supposed to take part immediately in their Husband's business, and they are therefore to be ticked on their respective lines in 4:1, unless they are expressly returned as following an independent occupation, in which case they must be dealt with as hereafter directed:--

Wife of Innkeeper, Hotelkeeper, Publican, Beerseller.

Wife of Lodging House, Boarding House-Keeper.

Wife of Shopkeeper (branch undefined).

Wife of Farmer, Grazier (but not of Farm Bailiff).

Wife of Shoemaker.

Wife of Butcher. ${ }^{8}$

\footnotetext{
7 'Drivers of Entrepreneurship and Small Businesses’, ESRC project grant ES/M010953.

8 'Instructions to the clerks employed in classifying the occupations and ages of the people', item 16, TNA RG 27/4 Census of England, Wales and Islands in the British Seas, 1871.
} 
However, these items were omitted from the instructions to the clerks from 1881 onwards. Those wives, who were previously taken as part of the employment totals, were no longer regarded as taking part in the labour force. Instead, they were consigned to the category of 'unoccupied'. Higgs argues that this was largely due to the changing paradigms of the Victorian social sciences in the late nineteenth century (Higgs 1987: 71). Such change persuaded the census authorities to reconstruct the occupational census from 1881 onwards in a form to emphasize more on paid labour in a market economy (ibid.).

The distortive effect of changes in the tabulation of 'occupation's wife' on constructing a consistent series of married women's LFPR over time has been acknowledged. McKay in addressing Hunt's assertion of a declining married women's LFPR over the second half of the nineteenth century (Hunt 1981: 18), compares married women’s employment figures in 1851 and 1911 published census reports (McKay 2007). While the employment totals give married women’s LFPR of about 25 percent in 1851, married women's LFPR in 1911 was just about ten percent. But after artificially deducting those wives from the 1851 employment totals, he finds that married women's LFPR in these two census years was actually at the similar level (McKay 2007).

The implication of 'occupation's wife' on calculating female LFPR in general is significant as well. Charles Booth, for example, had to artificially re-assign wives included in the pre-1881 employment totals to the unoccupied category in order to arrive at a more consistent series of female LFPR over time (Booth 1886). With this revision, it can be shown that a ten percent point gap in female LFPR between 1851 and 1911 would largely disappear.

Consistency, however, does not necessarily mean accuracy. Firstly, part of the census authority's assumption behind the inclusion of these wives in the employment totals rings true. It was probable that some of these wives were engaged in the same trade with their husbands. 
Even if they were not paid as others with independent occupational titles, the produce of their labour was likely to enter a wider market economy rather than just for home consumption. In that sense, they were unmistakably a part of the market economy. Secondly, the aforementioned treatment of 'occupation's wife' ignored the time-variant aspect of the likelihood of married couples working together. Given the changes in the underlying economy, the opportunities for married couples working together in the same trade may have indeed become more limited over time. Therefore, deducting all these wives from the employment totals between 1851 and 1871 would produce an underestimation of married women's LFPR as well as female LFPR in general. However, the scale of the underestimation depends on if the number of married women returned in the published censuses as 'occupation's wife' faithfully reflected the true level of their work in the same trade with their husbands. Unfortunately, this is unlikely to be true.

The number of married women returned in the published census reports as 'occupation's wife' is likely to represent a form of over-reporting of female employment. It can be revealed that this occupational title hardly had any discriminate nature concerning married women's actual employment. The fact that they were married to men in these occupations alone sufficed for them to be considered as being employed. The aforementioned instructions to census clerks provide the first clue. These instructions seem to suggest the clerks to tabulate all married women whose husbands were farmers and butchers etc. as 'farmer's wife' and 'butcher's wife', unless they were returned with independent occupational titles in the CEBs. However, to what extent these instructions were faithfully executed by the clerks remains unclear, unless we can directly compare the published figures with those extracted from the CEBs.

[insert Table 1 here] 
Table 1, using the census year of 1851 as an example, compares the number of married women returned as 'occupation's wife' in the published census reports with the corresponding figures extracted from the CEBs. The first column states husband's occupations. It shows that these instructions to the clerks were indeed well implemented. Across all these occupations, the proportion of married women who were tabulated as 'occupation's wife' in the published reports (column VI) is always radically higher than the proportion of married women being enumerated as such in the CEBs (column IV). For instance, less than ten percent of women married to shoemakers were enumerated as 'shoemaker's wife' in the CEBs. However, the published census reports tabulated nearly 85 percent of women married to shoemakers as 'shoemaker's wife'. It is clear that, apart from those married women enumerated as such in the CEBs, clerks also tabulated married women with no stated occupation as 'occupation's wife' in the published reports. In addition, there is also evidence suggesting that some clerks went against the instruction and even tabulated some married women with independent occupational titles in the CEBs as 'occupation's wife' in the published reports. Had the clerks only tabulated those married women who were enumerated either as 'occupation's wife' or with no occupational title in the CEBs as 'occupation's wife' in the published reports, column VII should be close to zero. However, that is not the case. For example, with regard to 'farmer's wife', column VII shows that 18 percent of all the 'farmer's wife' tabulated in the published reports cannot be accounted for by married women either recorded as 'occupation's wife' or with no occupational title in the CEBs. The only possible explanation is that some married women with independent occupational titles in the CEBs were instead tabulated as 'farmer's wife' in the published reports.

The different recording rates of 'occupation's wife' between the CEBs and the published reports on its own cannot gauge which one is more accurate. However, unless in reality almost all married couples in farming and inn keeping etc. worked together, as Table 1 suggests, the 
published reports between 1851 and 1871 overestimated the number of married women working with their husbands in those trades. Meanwhile, the published reports may have underreported the number of married women working with their husbands in other trades. The list of 'occupation's wife' included in the published reports was unlikely to be exclusive. There may have been other occupations in which married couples worked together in the same trade. So a question still remains: what was the true level of married women's employment with their husband in the same trade? If the published census figures could tell us little about this issue, would the original enumeration in the CEBs be able to solve the puzzle? This will be the focus of the following sections.

\section{III: 'Occupation's Wife' in CEBs}

The scale of the enumeration of married women as 'occupation's wife' in the CEBs is massive, at least between 1851 and 1881 . Table 2 shows the proportion of married women enumerated with independent occupational titles and as ‘occupation's wife' in the CEBs between 1851 and 1911. There were nearly as many married women enumerated as 'occupation's wife' as those with independent occupational titles between 1851 and 1881. In the 1881 CEBs, there were even more former than the latter. In addition, it can be shown that, up until 1881, the number of married women enumerated as 'occupation's wife' was almost ten times larger than that enumerated with the most common independent occupational title; and three times as large as the collective group that enumerated with the top five most common independent occupation titles. The enumeration rate of 'occupation's wife' in the CEBs declined dramatically after 1881. But even so, married women enumerated as such still represented a substantial group of married women with any occupational titles. Taking the census year of 1901 as an example when the enumeration rate of 'occupation's wife' was the lowest, it was still the fifth largest ‘employer’ of married women out of about six hundred standardized occupations in the CEBs. Without any doubt, 'occupation's wife' as a generic occupational group accounted for more 
married women's employment than any independent occupational title in the CEBs between 1851 and 1911.

\section{[insert Table 2 here]}

Apart from the sheer number of women enumerated as 'occupation's wife' in the CEBs, its enumeration was also prevalent across a wide spectrum of occupations. As shown in the previous section, there were only five occupations against which 'occupation's wife' was tabulated in the published census reports. However, many more occupations had the corresponding enumeration of 'occupation's wife' in the CEBs. Again, taking the 1881 CEBs as an example, it can be shown that, out of all the standardized occupations where married men's employment can be found, all but three had corresponding enumerations of 'occupation’s wife'.

The large number of married women enumerated as 'occupation's wife' in the CEBs as well as the wide spectrum of occupations involved in such enumerations are puzzling. As mentioned above, there were instructions to census clerks as what and how to tabulate 'occupation's wife' in the published census. But no such instructions related to 'occupation's wife' were given to householders or enumerators in producing the CEBs. The only entity on the household schedule that may have had a weak link to the enumeration of 'occupation's wife' in the CEBs was 'farmer's wife' given as an example on how to fill up the occupational column. But no other 'occupation's wife' was given as an example. Many enumerators and householders before 1891 may have taken the single example of 'farmer's wife' in the household schedule as a general guidance to record married women as ‘occupation’s wife’ regardless of their husband’s occupations. Even the example of 'farmer's wife' was dropped out of the household schedule after 1881. This change may partly explain the dramatic decline on the enumeration of 'occupation's wife' in the post-1881 CEBs. However, whether this simple change was 
powerful enough to account for such a dramatic decline is still debatable. More research should be directed towards it. But it is beyond the scope of this article to develop this topic any further.

As the criteria by which married women should be enumerated as ‘occupation's wife' remains a black box, this creates a conceptual ambiguity and leaves much room for different interpretations. Most intuitively and straightforwardly, one may argue it represented married women's labour in the form of working together with their husband in the same trade. This was also the reason behind the census authorities' decision to include certain 'occupation's wife' in the employment totals in the published census report between 1851 and 1871. In this case, married women who were enumerated as 'occupation's wife' in the CEBs should be rightly regarded as being active in the labour market. But at the same time, one may also argue this term is more of an acknowledgement of married women's domestic contribution at home such as washing, cooking and childcare. In this case, they probably should not be included in the calculation of total employment for two reasons. First, no one can deny the economic value of married women's domestic contributions. They greatly reduced the opportunity cost of family members’ participation in the labour market (Field 2013: 257; Horn 1990: 124-32, 184-8). But they did not possess the same characters as those, such as weaving in factories, which received monetary returns and whose output directly entered the market economy. Should they be included in the employment figures in the same way as those with independent occupational titles, the employment totals could be misleading. Second, within the broader socioeconomic environment, married women were almost always responsible for unpaid domestic labour (Aktinson 2012: 154-8; de Vries 2008: 186-9; Perkin 1989: 141-6; Rose 1992: 93-100; Ross 1993; Seccombe 1986). Should only those married women enumerated as 'occupation's wife' be regarded as participating in the labour market, we will be implicitly applying different definitions to the same work done by married women. Meanwhile, if we recognize all married women's domestic contribution as labour force participation, then married women's LFPR 
would be nearly 100 percent. Distinctions between different types of married women's work are needed to avoid such meaningless statistics in the context of calculating LFPR. This is not to undermine the value of married women's domestic work. It only suggests that different frameworks are needed to analyze married women's domestic work and gainful employment separately.

\section{[Insert Figure 1 here]}

The prevalence of 'occupation's wife' in the CEBs together with the difficulty of interpreting its true meaning has an overwhelming implication in studying married women’s LFPR from the CEBs. Perhaps the most obvious example is when one tries to analyze the spatial patterns of married women's LFPR. Figure 1 compares the spatial patterns of married women's LFPR by making different assumptions with regard to the status of 'occupation's wife' in the labour force, namely either assuming they were active in the labour market and included in the female labour force or they were not directly a part of the market economy and excluded from the female labour force. Three distinctions can be drawn. First, married women's LFPR would become higher in more than 75 percent of all parishes if we assume 'occupation's wife' was active in the labour market. Second, much fewer parishes would have zero percent married women’s LFPR if we assume ‘occupation's wife’ was active in the labour market. For instance, more than 21 percent of all parishes would have a married women's LFPR of zero percent if we assume 'occupation's wife' was not active in the labour market. But this figure would drop to nine percent if we assume the opposite. Third, and more importantly, different assumptions about 'occupation's wife' would lead to dramatic changes in the relative spatial pattern of married women's LFPR. Married women's LFPR derived only from the independent occupational titles (map on the left panel in Figure 1) shows a spatial pattern that is clearly associated with the economic geography, particularly concerning the demand for female labour. While most of the country saw married women's LFPR below ten percent, higher rates can be 
found in areas where demand for female labour was greater, for instance, the cotton districts in Lancashire, woolen districts in Yorkshire West Riding, straw plaiting and lacemaking districts in South East Midlands, nail making districts in West Midlands, and silk manufacturing districts on the Suffolk and Essex border. ${ }^{9}$ The spatial pattern of married women's LFPR appears very different if one assumes ‘occupation's wife’ was active in the labour market (map on the right panel in Figure 1). On the one hand, West Wales and the Pennines would see clear concentrations of high levels of married women's LFPR. This may partly be explained by the prevalence of small family farms and dairy farms in these regions. On the other hand, the areas identified with higher married women's LFPR on the left panel in Figure 1 cease to stand out in comparison with the rest of the country on the right panel. Instead, many parishes with married women's LFPR greater than 80 percent can be found scattered around the country.

It is clear that the conceptual ambiguity as well as the large scale of 'occupation's wife' recorded in the CEBs create an empirical uncertainty concerning married women's labour force participation. This empirical uncertainty in turn could imperil historians' endeavors to answer important questions such as: (i) what was the true level of married women's employment? (ii) what was the driving forces behind married women's labour force participation? (iii) how did married women respond to socioeconomic variations both inside and outside the home? The key to solve this problem is to ascertain which aspect of married women's work ‘occupation's wife' tried to capture in the CEBs.

\section{IV: Working with Husband?}

\footnotetext{
${ }^{9}$ Higher female LFPR in general, thanks to higher demand for female labour, can be found in these areas as well. See Shaw-Taylor, 'Diverse experiences'.
} 
The seemingly most credible hypothesis is that the term 'occupation's wife' represents married women's labour in the form of working together with their husbands in the same trade (Humphries 2016). Under this hypothesis, the fact that, for example, 11 percent of women married to shoemakers were enumerated as 'shoemaker's wife' in the 1881 CEBs should be interpreted as about 11 percent of women married to shoemakers working together with their husband in shoemaking. An effective way to test this hypothesis is to investigate the enumeration of 'occupation's wife' by husband's occupation in the CEBs. If this hypothesis holds true, we would expect to observe the enumeration of 'occupation's wife' only in or, at least highly skewed towards, economic sectors and occupations that were largely household based mainly utilizing labour input from family members.

\section{[insert Table 3 here]}

The evidence from the CEBs goes against this hypothesis. Taking the 1881 CEBs for example, Table 3 shows the proportion of married women enumerated as 'occupation's wife' by their husband's employment sector and major sub-sectors in the PST occupational classification scheme. ${ }^{10}$ Two messages become immediately clear. First, ‘occupation’s wife’ can be found in all economic sectors and sub-sectors, even when there was virtually no room for married couples to work together in the same trade. Second, even with variations, the enumeration rate

${ }^{10}$ Under the PST scheme, people’s occupations were categorized into three broad sectors: primary, secondary and tertiary. The primary sector included all extractive economic activities related to the production of raw materials such as agriculture and mining. The secondary sector refers to economic activities associated with transformation of raw materials produced by the primary sector into other commodities. For example, it includes occupations such as builders and textile workers. The tertiary sector refers to occupations associated with all types of services such as domestic service, retailing, wholesale, transport and professions. 
of 'occupation's wife' did not show clear skew towards economic activities such as earthenware manufacture and shoemaking that had greater likelihood for married couples to work together in the same trade. This suggests that 'occupation's wife' fails to distinguish between different groups of married women based on their actual form of labour input and provides little indication of married women working together with their husband in the same trade.

The primary sector had the highest enumeration rate of 'occupation's wife'. Agriculture and fishing are probably the only two sub-sectors within the primary sector that offered the possibility for married women to work with their husband in the same trade. Some women married to farmers helped the daily running of the farm (Ellis 1750; Henry 1771: 23; Loudon 1831: 1036; Verdon 2003). Agricultural labourers’ wives were sometimes found working with their husbands in harvesting (Burnette 2007; Verdon 2002: 120). Fishermen’s wives were likely to be engaged in activities such as gutting, baiting and net-repairing in the inshore fisheries. Other economic activities in the primary sector such as forestry and mining were extremely unlikely to offer such possibility. However, the recording of 'occupation's wife' can be found in these sub-sectors as well with similar enumeration rates. But it would certainly be wrong to argue, for example on the basis of the enumeration of 'miner's wife', that nearly 15 percent of women married to miners were also employed in mining. ${ }^{11}$ Similar observations can be found in the secondary and tertiary sectors as well. Within the secondary sector, clothing, footwear and earthenware were in reality more likely to have married women working with

\footnotetext{
${ }^{11}$ Since the Mines and Collieries Act of 1842, women were prohibited from working underground in collieries. Humphries, 'Protective legislation'. It can be shown from the 1851 census that adult women only accounted for two percent of the entire adult workforce in coal mining in England and Wales.
} 
their husband in the same trade (Dupree 1995). The enumeration rate of 'occupation's wife' in these sub-sectors were around ten percent. However, similar enumeration rates can also be found in industries such as building and construction as well as iron and steel manufacture. These sub-sectors are well known for the near absence of female workforce (Burnette 2008: 19-20; Jordan 1988, 1989;). It is beyond doubt there was little room for married women to work together with their husband in the same trade in these sub-sectors. Within the tertiary sector, there was room for married couples to work together in selling and hawking. However, the similar enumeration rate of 'occupation's wife' can also be found in professions and services as well as transport. The sub-sector professions and services included occupations such as lawyers, bankers and managers. It is highly unlikely that women married to these professionals would work in the same trade. Neither was it likely that married women whose husbands were employed in transport, such as railway engineers or stagecoach drivers, worked together with their husband in the same trade.

The argument that the term 'occupation's wife' indicates little about married women's labour in the form of working together with their husband in the same trade becomes even more apparent if we analyze its enumeration rate by husband's specific occupations. As alluded to in the previous section, out of all the standardized occupations where married men's employment can be found, all but three had the corresponding enumerations of 'occupation's wife' in the 1881 CEBs. This is perhaps the most revealing evidence against the claim that married women who were enumerated as 'occupation's wife' in the CEBs worked with their husband in the same trade. It is simply inconceivable that almost all occupations in the British economy in the last quarter of the nineteenth century could offer such opportunities.

Occupations such as shopkeepers and shoemakers were indeed likely to have married couples working together, and hence the correspondingly 'occupation's wife' was included in the employment totals in some published reports. However, it can be shown that the enumeration 
rate of 'occupation's wife' for most occupations in the CEBs was similar to those such as shopkeeper and shoemaker. For example, the mean and median enumeration rates among all 'occupation's wife' in the 1881 CEBs were 13.8 percent and 10.1 percent as against 11.5 percent for 'shopkeeper's wife'. That is to say, most married women were almost equally likely to be enumerated as 'occupation's wife' regardless of whether in reality they worked with their husband in the same trade or not. Furthermore, it can be shown that the number of married women enumerated as 'occupation's wife' in the CEBs for those occupations such as farmers and shoemakers, which were more likely to employ married couples together only covered less than fifth of all married women who were enumerated as 'occupation's wife' in the CEBs. The rest of the occupations, which were less likely to have married couples working together, accounted for the majority of married women enumerated so in the CEBs.

The argument that 'occupation's wife' in the CEBs indicates little about married women working with their husband in the same trade can be further strengthened by analyzing the enumeration rate of 'occupation's wife' by Enumeration District (hereafter ED). It can be shown that there were enumerators who simply recorded all married women in their EDs as 'occupation's wife'; a significant proportion of enumerators recorded almost all married women in their EDs as 'occupation's wife'; and a large number of enumerators did not use the term 'occupation's wife' in their enumeration at all. This is strong evidence showing that enumerators, when deciding whether to use 'occupation's wife' as an occupational title, paid little attention to the fact of whether married women actually worked with their husband in the same trade or not. The indiscriminate nature of the enumeration of 'occupation's wife' in many cases as well as the absence of the enumeration of 'occupation's wife' in others strongly suggests that its enumeration was heavily influenced by enumerators’ idiosyncrasies. It bears little resemblance to the true level of married women working with their husbands. 
As alluded to in Section I, parishes and EDs often do not coincide (Higgs 2005: 37-8). While parishes identifiers are available for all census years in I-CeM database, ED identifiers are currently only available for the census year $1861 .{ }^{12}$ So let us use 1861 as an example. The results pertaining to the enumeration of 'occupation's wife' by ED in the 1861 CEBs are presented in Table $4 .{ }^{13}$ Nearly 270 enumerators recorded all married women in their districts as 'occupation's wife'. The number of married women in these districts is greater than 12,000 . It is inconceivable that, regardless of the local economic conditions and their husband's occupations, all married women from these districts worked together with their husbands in the same trade. It is the clearest example of enumerators' idiosyncrasies presiding over reality to yield faulty enumeration practice in the extreme.

\section{[insert Table 4 here]}

In comparison with the total number of EDs where 'occupation's wife' can be found and the total number of married women enumerated as such in the country, the corresponding figures from these 269 districts may not seem particularly large. However, this is not the only case showing the effect of enumerators' idiosyncrasies on the enumeration of 'occupation's wife'. Many enumerators recorded almost all married women in their districts as ‘occupation's wife’. With regard to the districts where more than 90 percent of married women were enumerated as 'occupation's wife', the number of married women enumerated as such in these districts accounted for nearly 25 percent of all married women enumerated as such in the country. With

\footnotetext{
${ }^{12}$ The I-CeM dataset that is released to the public does not contain unique ED identifiers. The author identified and created such identifiers for 1861. I would like to thank Kevin Schurer for discussions on the exact procedure for identification.
}

${ }^{13}$ Not all EDs have been successfully identified. According to the General Report of the 1861 Census, there were 30,329 EDs in England and Wales. 28,584 of them have been identified. 
regard to the districts where more than 75 percent of married women were enumerated as ‘occupation's wife', this figure jumps to more than 40 percent (Column VI).

The fact that not all married women were enumerated as 'occupation's wife' in these districts does not necessarily mean that careful deliberations were made by enumerators as to whether married women worked with their husband or not. Column VII in Table 4 shows that, on average, the population size of these districts was much larger than that of the districts where all married women were enumerated as 'occupation's wife'. This implies, and as supported by Column VIII in Table 4, that these more populated districts can be expected to have a more diverse labour market. This in turn made it more likely for some married women to have independent occupations outside the home. In this case, male household header would be likely to return these married women as someone with independent occupational titles in the household schedule. Given this, it is unlikely that enumerators would deliberately go against what was recorded in the household schedules and record all married women as ‘occupation's wife' instead. This is the reason why not all married women were recorded as 'occupation's wife' in these EDs. But the high enumeration rate of 'occupation's wife', say more than 90 percent, nevertheless indicates that for married women without an independent occupational title in these EDs, they were enumerated as ‘occupation's wife' anyway regardless of whether they worked with their husband in the same trade. In that sense, the term 'occupation's wife' to some extent managed to separate those women enumerated as such from those enumerated with independent occupational titles, depending on whether or not they regularly participated in the labour market outside the home. But for married women who were enumerated as 'occupation's wife', it still failed to separate those who were genuinely working together with their husband in the same trade from those who were not.

On the other extreme, there were EDs where no married women were enumerated as 'occupation's wife' at all (penultimate row in Table 4). The number of this type of EDs 
accounted for more than 35 percent of all the EDs in the country. This is another strong piece of evidence supporting the argument that the enumeration of 'occupation's wife', or the lack of it, heavily depended on individual enumerators' idiosyncrasies. If the enumeration of 'occupation's wife' were to capture married women's work with their husband, one should expect to find a marked difference in married men's occupational structure between EDs with the enumeration of 'occupation's wife' and EDs without. The latter should have almost no occupations that could offer married couples the opportunity to work together. But it can be shown from the 1861 CEBs that married men from the former group of districts were employed in 703 occupations out of the total of 707, while married men in the latter group can be found in 705 occupations. The potential scope for married couples to work together in the same trade was similar between these two groups of EDs. Table 5 shows married men's occupational structure in these two groups of EDs. There is a difference between the two with the primary sector covering a larger share of married men's employment in the EDs with the enumeration of 'occupation's wife' than those without. Given the higher enumeration rate of 'farmer's wife' identified in Section IV, this can partly explain the higher probability of finding 'occupation's wife' in the former group of EDs but it cannot at all explain the complete absence of 'occupation's wife' in the latter group. Instead of difference, the most important message from Table 5 is actually the similarity of married men's occupational structure between these two groups. It is clear that the latter group of EDs also offered opportunities for married couples to work together in the same trade. On the one hand, as shown before, enumerators' idiosyncrasy led to an overestimate of the scale of married couples working together in many of the districts in the former group. On the other hand, it led to an extreme underestimate in the latter group.

\section{[insert Table 5 here]}

Individual enumerators' idiosyncrasies in the enumeration of 'occupation's wife' was likely to be the product of Victorian domestic ideology. Originating from the Evangelical movement 
and widely supported by the British middle and upper classes, Victorian domestic ideology assumed and promoted the key role of women as the 'angel at home' offering companionship and care to other household members as wives, mothers, daughters or sister (Hall 1979; Rose 1986). It argued that this domestic position was the only proper role for which women should be recognized and it discredited and discouraged women's physical toil as inappropriate to their gender and morally corrupting. ${ }^{14}$ It is still debatable how far this ideology trickled down the social hierarchy and to what extent it altered most families' labour supply strategy in light of economic reality (Vickery 1993). But based on the enumeration patterns of 'occupation’s wife' in the CEBs, it is clear that many male enumerators were more than willing to recognize married women solely through their supposed domestic position as someone's wife. In that sense, 'occupation's wife' seems to be more of a domestic title than an occupational title. Instead of showing married women's employment, it was more indicative of the gender relationship in Victorian England and Wales. The male adherence to rigid gender role and domestic status quo, it appears, turned a blind eye to many married women’s economic function as wage earner or family business partner, even if in many cases married women's work with their husband was crucial in the household economy characterized by frail breadwinners. The lack of enumeration of 'occupation's wife' in many other EDs does not mean they were free from the influence of this domestic ideology either. In a different form, it led male enumerators to completely ignore married women's work, either with their husband or outside the home, and gave them no recording under the occupational column at all. The under-reporting of married women's employment in this form is well documented by the existing literature (Higgs 1987).

\footnotetext{
${ }^{14}$ For example, see B.P.P. XVI, 1842: 246; B.P.P. LXXV, 1844: 144; B.P.P. XXII, 1861:
} 698. 
By examining the enumeration of 'occupation's wife' by husband's occupation and EDs, this section shows that its enumeration was heavily influenced by individual enumerators' idiosyncrasies, which was possibly the result of Victorian domestic ideology. The term 'occupation's wife' had little credibility in indicating married women's labour in the form of working together with their husband in the same trade for most occupations. However, one question remains: did the enumeration of ‘occupation's wife' at least capture married women’s work with their husband in occupations such as farmer and shoemaker where the likelihood of married couples working together was higher? Using farmer and farmer's wife as an example, this will be the focus of next section.

\section{V: Farmer's Wife as a Case Study: Their Work and CEB Recordings}

The enumeration of 'farmer's wife' in the CEBs is a good case study to test the hypothesis put forward at the end of the last section. Whether married couples worked together in the same trade did not only depend on the type of husband's trade but also the nature and the scale of the business operation. While such information is not readily available in the CEBs for most occupations, it is available for farmers. The scale of farmers' business operation can be assessed by farm acreage.

In the census household schedules, farmers were asked not only to return their occupation but also the acreage of his or her farm as well as the number of labourers employed on the farm. ${ }^{15}$ For example, one item from the instructions to householders on how to fill in the household schedule in 1881 reads:

\footnotetext{
${ }^{15}$ For example, see Census of England and Wale, 1881, Vol. IV, General report, B.P.P. 1883 LXXX [C.3797], 116.
} 
FARMERS to state the number of acres occupied, and the number of men, women, and boys employed on the farm at the time the Census._Example: "Farmer of 317 Acres, employing 8 Labourers and 3 Boys.”

The information pertaining to farm acreage have been extracted from the 1881 CEBs as part of the Entrepreneurship Project led by Bennett at Campop. ${ }^{16}$ However, it should be noted that not all farmers followed the instructions given to them. Some of them simply recorded themselves as farmer without giving any information on farm acreage. Out of 263,933 farmers identified in the 1881 CEBs, 198,097 of them, i.e. about 75 percent, returned farm acreage information. Out of 172,098 married male farmers identified in the 1881 CEBs, 135,900 of them, i.e. about 80 percent, returned farm acreage information. The rest of the section will only focus on farmers who returned farm acreage.

The existing historiography identified an inverse relationship between farm size and likelihood of family members' engagement in farming activities. Allen argues that farms of 50 to 60 acres were family farms and could be operated by family members without much hired labour. On the other hand, farms of more than 100 acres were capitalist farms and were run predominately by hired labour. Farms of 60 to 100 acres, in the middle, were transitional farms employing roughly equal amount of family and hired labour (Allen 1992: 57). Shaw-Taylor criticizes Allen's approach of applying a single set of acreage thresholds to capture the characteristic of farming employment across the country. He finds the threshold of farm acreage by which no hired labour was required varied greatly across the country. However, despite the regional diversity, he too finds a general inverse relationship between farm size and likelihood of family labour in farming (Shaw-Taylor 2012). In counties south and east of a line between Dorset and the Wash, average farm sizes were much larger than the rest of the country, and the proportion

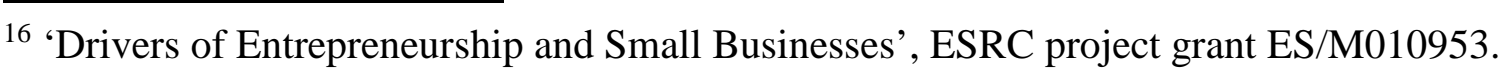


of farms utilizing any family members' labour in these counties was much smaller than the rest of the country (ibid.: 35-9). This inverse relationship was recognized by contemporary observers as well. While farmers' wives in large farms were criticized for retreating back to the home and distancing themselves from farming activities, farmers' wives in small farms were praised for their farming labour in assisting their husband (Cobbett 1985 [1830]: 226-7; Howitt 1884: 104; Loudon 1831: 1036). Verdon, drawing on evidence from contemporary manuals and encyclopedias, highlights the fact married women in smaller farms were more likely to be involved in farming activities than married women in large farms (Verdon 2003). The distinction between the activities of farmers' wives by farm size was clearly marked over the nineteenth century. Farmers' wives in large farms, who were enabled by healthy family income and being status conscious, increasingly distanced themselves from the farming activities. This led William Cobbett to describe them as the ‘Mistress Within’ (Cobbett 1985 [1830]: 229). But at the same time, farmers' wives in small farms, particularly in north west England, were still engaged in a wide spectrum of customary farming activities, ranging from manual labour on the field, pig rearing, poultry keeping, cheese making, beekeeping and food preserving, that formed an integral part of the household economy (Verdon 2003: 34-5; Winstanley 1996). Apart from farm size, the function of the farm, namely whether being an arable farm or dairy farm, is also a factor affecting the likelihood of married women's engagement in farming activities. Before the nineteenth century, dairy work, either manual or supervisory, was seen as a natural task of farmer's wife (Verdon 2003: 28-9). However, given the increasing commercialization over the nineteenth century, even within dairy farming, farmer's wife on large dairy farms increasingly distanced themselves from dairy work while those on small dairy farms continued their tradition role (Valenze 1991: 166).

Given the inverse relationship between farm size and married women's engagement in farming activities, were the enumeration of 'farmer's wife' to faithfully record married women's labour 
activities in farming, one would expect to find the enumeration rate of 'farmer's wife' decrease significantly with farm acreage.

\section{[insert Figure 2 here]}

Figure 2 shows the proportion of women married to farmers that were enumerated as 'farmer's wife' by farm size in the 1881 CEBs. The results go against the aforementioned hypothesis. The enumeration rate of 'farmer's wife' does not show any significant variations by farm size. It is remarkably similar between 40 and 50 percent across a wide range of farm sizes with increments of 20 acres. ${ }^{17}$ This is yet the strongest evidence going against the argument that 'farmer's wife' in the CEBs captured married women's work with their husband in farming. The question concerning the acreage thresholds between family farms and capitalist farms may never be settled. However, the detailed break-down of farm acreage in Figure 2 means that both types of farms must have been covered here. It shows that married women from large capitalist farms, which were run predominately by hired labour with almost no need for family labour, were just as likely to be enumerated as 'farmer's wife' as their counterparts from small family farms where married women were more directly and actively engaged in farming. For example, 42.5 percent of married women in farms smaller than 20 acres were enumerated as 'farmer's wife' in the 1881 CEBs. The corresponding figures for married women in farms larger than 400 acres was just one percent point lower. Allen finds that farmers on average had an annual income of $£ 159.22$ in 1867, which can be translated into twelve consumption baskets (Allen 2019: 106). Farming families holding farms greater than 400 acres must surely have had

\footnotetext{
17 The enumeration rate of 'farmer's wife' for those farms without returned acreage information was lower. But even if, in extreme, we assume all these farms were in reality to be found in one particular group of farm size, the enumeration rate of 'farmer's wife' for the corresponding group would still be similar to the average trend.
} 
an annual income much greater than that. Given the high levels of income, genteel status, and adherence to middle-class behavioural codes, it is hard to imagine married women from these large capitalist farms being directly involved in farming. The similar enumeration rates by farm size hint at a strong element of randomness involved in the enumeration of 'farmer's wife' as a result of the hitherto mentioned enumerators' idiosyncrasies. It bears little, if any, indication of married women's labour activities in farming.

\section{[insert Table 6 here]}

Table 6 can further support the aforementioned argument. It shows the enumeration rate of 'farmer's wife' by ED in 1861 CEBs. ${ }^{18}$ In comparison with Table 4 which concerns the enumeration of 'occupation's wife' in general, the effect of enumerators' idiosyncrasies on the enumeration of 'farmer's wife' becomes even more apparent. Out of 10,418 EDs where 'farmer's wife' can be found, 3,537 enumerators, that is nearly 35 percent, had all women married to farmers in their EDs enumerated as 'farmer's wife'. The number of women enumerated as 'farmer's wife' from these EDs accounted for more than 40 percent of all married women enumerated as such in the country. This is clearly a case of the enumerators failing to distinguish between different groups of married women based on their actual labour activities. It is a serious overestimate of married women's labour input into farming in these districts. By contrast, 10,147 EDs out of the total of about 20,000 EDs, which had married male farmers recorded, had no enumeration of 'farmer's wife' at all. Some married women from these EDs surely worked with their husband on the farms. The fact that none of them were enumerated as 'farmer's wife' constitutes a serious underestimate of married women's labour activities in farming. It shows once again how enumerators' idiosyncrasy can distort the picture

${ }^{18}$ Limited by the availability of unique ED identifiers, this analysis is so far only possible for 1861. 
of reality. The previous section suggests that the enumeration of 'occupation's wife' had little indication of married women's labour in the form of working together with their husband for most occupations. This section shows that, even with regard to occupations that offered greater possibilities for married couples to work together, 'occupation's wife' still bears little indication of married women's actual labour activities.

\section{VI: Caveats}

The task of finding the true meaning of 'occupation's wife' is complicated. The results presented in this article surely have caveats. First, the fact that 'occupation's wife' in the census failed to capture married women's work with their husband does not mean such work did not exist. Many married women, in reality, undoubtedly worked with their husband in the same trade. However, we should not use 'occupation's wife' in the census to analyze such work. More suitable sources such as diaries and autobiographies should be consulted instead. Second, even though 'occupation's wife' in the census did not capture married women's employment, could this term mean something else? The most obvious candidate is married women's domestic function such as cooking, washing and childrearing. It is difficult to ascertain this argument. Married women were almost always responsible for unpaid domestic labour in the nineteenth century. Those married women who were recorded as 'occupation's wife' were undoubtedly in charge of domestic chores. But so were those who were not recorded so. We should not use 'occupation's wife' as an exclusive indicator of whether married women were engaged in domestic duties or the intensity of their domestic duties. Third, for some married women, their occupational title of 'occupation's wife' could be a meaningful indicator of their work with husband in the same trade. Take part of one ED in the parish of Owthorne in Yorkshire in 1861 for example. Table 7 shows that, among ten married couples in this area, two married women were enumerated as 'occupation's wife'; six married women were enumerated with independent occupational titles; and the remaining two had no occupational 
descriptors at all. The question then needs to be asked if those two married women in records 1 and 2 were not working with their husband, why did the enumerators just give them no occupational descriptor at all like records 9 and 10. In this case, deliberations were clearly being made by this enumerator as to whether married women were working or not and whether married women were working with their husbands or not. Unfortunately, it is beyond the scope of this article to identify all the EDs of this type and offer a detailed analysis.

\section{[insert Table 7 here]}

\section{VII: Conclusion}

This article delineates how 'occupation's wife' was tabulated in the published census reports and how 'occupation's wife' was enumerated in the CEBs. It argues that 'occupation's wife', either in the published census reports or in the CEBs, in general had little indication of married women's labour in the form of working with their husband in the same trade.

With regard to the published census reports, this article shows that, on one hand, 'occupation's wife' was not regarded as being part of the employment totals between 1881 and 1911, i.e. an extreme underestimation. On the other hand, the tabulation of 'occupation's wife' between 1851 and 1871 is likely to be an overestimation for certain occupations. Almost all women married to men in the occupations such as farmers and shoemakers were tabulated as 'occupation’s wife' even if they were not recorded so in the original manuscripts, i.e. CEBs.

With regard to the CEBs, this article shows that almost all occupations had the corresponding enumeration of 'occupation's wife' in the CEBs, even if the occupations offered almost no opportunities for married couples to work together. It is also revealed that enumerators did not use this occupational title with careful deliberation to distinguish between married women who worked with husband and married women who did not. Some enumerators simply recorded all 
or almost all married women in their EDs as 'occupation's wife', and at the same time, many enumerators recorded none of married women in their EDs as 'occupation's wife'. It suggests that the enumeration of 'occupation's wife' was heavily influenced by enumerators' idiosyncrasy possibly as a result of Victorian domestic ideologies. Instead of showing married women's employment, the enumeration of 'occupation's wife' in the CEBs was more indicative of the gender relationship in Victorian England and Wales. Its enumeration patterns suggest that many men were just more than willing to recognize married women solely through their supposed domestic position as someone’s wife. In that sense, 'occupation's wife' is more of a domestic title than an occupational title.

Married women's non-domestic work could take many different forms. As shown in other studies, their regular gainful employment outside the home was, to some extent, faithfully recorded in the census (You, 2019). However, this type of employment does not make up the entirety of married women's work. The work with husband in the same trade, among some married women, was likely to constitute a sizeable part of married women’s total labour input. However, the census was inadequate to shed much light on this issue. For this particular form of married women's employment, alternative sources to the official statistics, such as diaries, autobiographies and household budgets, must be consulted for a more accurate re-assessment.

\section{$\underline{\text { References }}$}

Aktinson, Paul (2012) “Isn’t it time you were finishing?: Women’s labour force participation and childbearing in England, 1860-1920.” Feminist Economics, 18 (4): 145-164.

Allen, Robert C (1992) Enclosure and the Yeoman. Oxford: Clarendon Press.

---- (2019) “Class structure and inequality during the industrial revolution: lessons from England’s social tables, 1688-1867.” Economic History Review, 72 (1): 88-125. 
Anderson, Michael (2007), “Mis-specification of servant occupations in the 1851 Census: a problem revisited,” in Nigel Goose (ed.), Women’s Work in Industrial England: Regional and Local Perspectives. Hatfield: Local Population Studies: 260-8.

---- (2007) “What can the mid-Victorian censuses tell us about variations in married women’s employment?” in Nigel Goose (ed.), Women's Work in Industrial England: Regional and Local Perspectives. Hatfield: Local Population Studies: 182-208.

Berg, Maxine (1993) "What difference did women’s work make to the industrial revolution?” History Workshop Journal, 35 (1): 22-44.

Booth, Charles (1886) “Occupations of the people of the United Kingdom, 1801-81.” Journal of the Statistical Society of London, (49): 314-444.

Bourke, Joanna (1994) “Housewifery in working-class England 1860-1914.” Past \& Present, 143 (1), 167-97.

Burton, Nick, and Southall, Humphry R (2004). GIS of the ancient parishes of England and Wales, 1500-1850. [data collection]. UK Data Service. SN: 4828.

Burnette, Joyce (2007) "Married with children: the family status of female day-labourers at two south-western farms.” Agricultural History Review, (55): 75-94.

---- (2008) Gender, Work and Wages in Industrial Revolution Britain. Cambridge: Cambridge University Press.

Cobbett, William (1830) Rural Rides. (1985 edition) Harmondsworth, UK: Penguin Books.

De Vries, Jan (2008) The Industrious Revolution: Consumer Demand and the Household Economy, 1650 to Present. Cambridge: Cambridge University Press.

Davidoff, Leonore, and Catherine Hall (1987) Family Fortunes: Men and Women of the English Middle Class, 1750-1850. London: Routledge.

Dupree, Marguerite W (1995) Family Structure in Staffordshire Potteries, 1840-1880. Oxford: Clarendon Press. 
Ellis, Williams (1750) The Country Housewife's Family Companion. London

Field, Jacob (2013) “Domestic service, gender, and wages in rural England, c.1700-1860.”

Economic History Review, 66 (1): 249-72.

Hall, Catherine (1979) “The early formation of Victorian domestic ideology.' in Sandra Burman (ed.), Fit Work for Women. London: Routledge: 15-32.

Hatton, Timothy J., and Roy E. Bailey (2001) “Women’s work in census and survey, 19111931.” Economic History Review, 54 (1): 87-107.

Henry, David (1771) The Complete English Farmer. London: F. Newbery.

Higgs, Edward (1987) "Women, occupation and work in the nineteenth century censuses." History Workshop Journal, (23): 59-80.

---- (2005) Making Sense of the Census Revisited. London: Institute of Historical Research.

Higgs, Edward, Christine Jones, and Kevin Schürer et al. (2013) “Integrated Census Microdata (I-CeM) Guide.” www1.essex.ac.uk/history/research/icem/documents/icem-guide-version-22015.pdf (accessed June 1).

Higgs, Edward, and Amanda Wilkinson (2016) "Women, occupations and work in the Victorian censuses revisited.” History Workshop Journal, 81 (1): 17-38.

Hill, Bridget (1993) "Women, work and the census: a problem for historians of women.” History Workshop Journal, 35 (1): 78-94.

Honeyman, Katrina (2000) Women, Gender and Industrialization in England, 1700-1870. Basingstoke: Palgrave Macmillan.

Horn, Pamela (1990) The Rise and Fall of the Victorian Servant. Sutton: The History Press Horrell, Sara, and Jane Humphries (1995) “Women's labour force participation and the transition to male-breadwinner family, 1790-1865.” Economic History Review, 48 (1): 89-117. Howitt, William (1884) The Rural Life of England. London: Longman. Hudson, Pat (1992) The Industrial Revolution. London: Bloomsbury Academic. 
Humphries, Jane (1981) “Protective legislation and, the capitalist state, and working class men: the case of the 1842 Mines Regulation Acts.’ Feminist Review, (7): 1-35.

---- (1990) "Enclosures, common rights, and women: the proletarianization of families in the late eighteenth and early nineteenth centuries.” Journal of Economic History, 50 (1): 17-42.

---- (2016) “2016 Ellen McArthur Lecture.” University of Cambridge, http://www.econsoc.hist.cam.ac.uk/podcast-humphries.html (accessed June 1).

Hunt, Edward H (1981) British Labour History. London: Weidenfeld \& Nicolson. Jordan, Ellen (1988) “Female unemployment in England and Wales 1851-1911: an examination of the census figures for 15-19 year olds.” Social History, 13 (2): 175-90.

---- (1989) “The exclusion of women from industry in nineteenth-century Britain.” Comparative Studies in Society and History, 31 (2): 273-96.

Kain, Roger and R. R. Oliver (2001). Historic Parishes of England and Wales : an Electronic Map of Boundaries before 1850 with a Gazetteer and Metadata. [data collection]. UK Data Service. SN: 4348.

Lemire, Beverly (2005) The Business of Everyday Life: Gender, Practice and Social Politics in England, c. 1600-1900. Manchester: Manchester University Press.

Loudon, John C (1831) An Encyclopedia of Agriculture. London: Longman.

Lown, Judy (1990) Women and Industrialization: Gender and Work in Nineteenth Century England, Cambridge: Polity Press.

McGeevor, Sophie (2014) “How well did the $19^{\text {th }}$ century census record women's 'regular' employment in England and Wales? A case study of Hertfordshire in 1851.” History of the Family, 19 (4): 489-512.

McKay, John (2007) "Married women and work in nineteenth-century Lancashire: the evidence of the 1851 and 1861 Census report.” in Nigel Goose (ed.), Women's Work in 
Industrial England: Regional and Local Perspectives. Hatfield: Local Population Studies: 16481.

Mills, Dennis and Kevin Schürer (1996) "Communities in the Victorian censuses: an introduction.” in Dennis Mills and Kevin Schürer (eds.), Local Communities in the Victorian Census Enumerators’ Books, Oxford: Local Population Studies: 1-15.

---- (1996) “The enumeration process.” in Dennis Mills and Kevin Schürer (eds.), Local Communities in the Victorian Census Enumerators' Books, Oxford: Local Population Studies: 16-26.

Perkin, Joan (1989) Women and Marriage in Nineteenth-Century England. London: Routledge. Roberts, Elizabeth (1995) Women's Work, 1840-1940. Cambridge: Cambridge University Press.

Rose, Sonya O (1986) “'Gender at work’: sex, class and industrial capitalism.” History Workshop Journal, 21 (1): 113-31.

---- (1992) Limited Livelihoods: Gender and Class in Nineteenth-Century England. Berkeley: University of California Press.

Ross, Ellen (1993) Love and Toil: Motherhood in Outcast London 1870-1918. Oxford: Oxford University Press.

Satchell, Max, Peter Kitson, and Gill Newton et al. (2016) 1851 England and Wales Census Parishes, Townships and Places. [data collection]. UK Data Service.

Schürer, Kevin, and Edward Higgs (2014) Integrated Census Microdata (I-CeM), 1851-1911. [data collection]. UK Data Service. SN: 7481.

Seccombe, Wally (1986) "Patriarchy stabilized: the construction of the male breadwinner wage norm in nineteenth-century Britain.” Social History, 11 (1): 53-76.

Sharpe, Pamela (1995) “Continuity and change: women’s history and economic history in Britain.’ Economic History Review, 48 (2): 353-69. 
---- (1996) Adapting to Capitalism: Working Women in the English Economy 1700-1850. Basingstoke: Palgrave.

Shaw-Taylor, Leigh (2007) “Diverse experiences: the geography of adult female employment in England and the 1851 Census.” in Nigel Goose (ed.), Women's Work in Industrial England: Regional and Local Perspectives. Hatfield: Local Population Studies: 29-50.

---- (2012) "The rise of agrarian capitalism and the decline of family farming in England." Economic History Review, 65(1): 26-60.

Valenze, Deborah (1991) “The art of women and the business of men: women’s work and the dairy industry c. 1740-1840.” Past \& Present, 130 (1): 142-69.

Verdon, Nicola (2002) Rural Women Workers in Nineteenth Century England: Gender, Work and Wages. Woodbridge: Boydell Press.

---- (2003) “ ‘... Subjects deserving of the highest praise’: farmers’ wives and the farm economy in England, c. 1700-1850.” Agricultural History Review, (51): 23-39.

Vickery, Amanda (1993) "Golden age to separate spheres? A review of the categories and chronology of English women’s history.” Historical Journal, 36 (2): 383-414.

Winstanley, Michael (1996) "Industrialization and the small farm: family and household economy in nineteenth-century Lancashire.” Past \& Present, (152): 157-95.

Woollard, Matthew (1998) "The classification of occupations in the 1881 census of England and Wales.” History and Computing, doi: 10.3366/hac.1998.10.1-3.17

You, Xuesheng (2019) “Women’s labour force participation in nineteenth-century England and Wales: evidence from the 1881 Census Enumerators’ Books.” Economic History Review, doi.org/10.1111/ehr.12876 
Figure 1. Spatial pattern of married women's LFPR in England and Wales, 1881

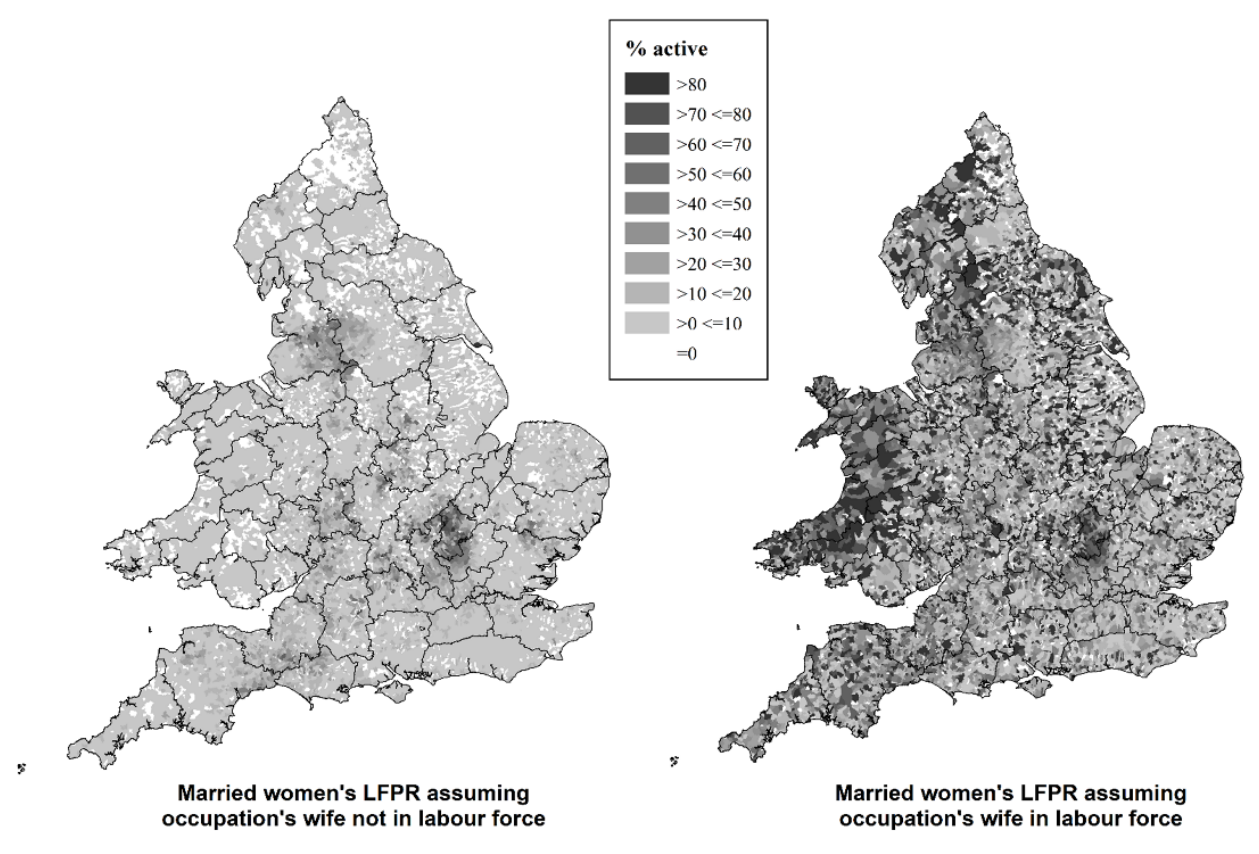

Sources: 1881 CEBs from I-CcM dataset 
Figure 2. Enumeration rate of 'farmer's wife' by farm size in England and Wales, 1881

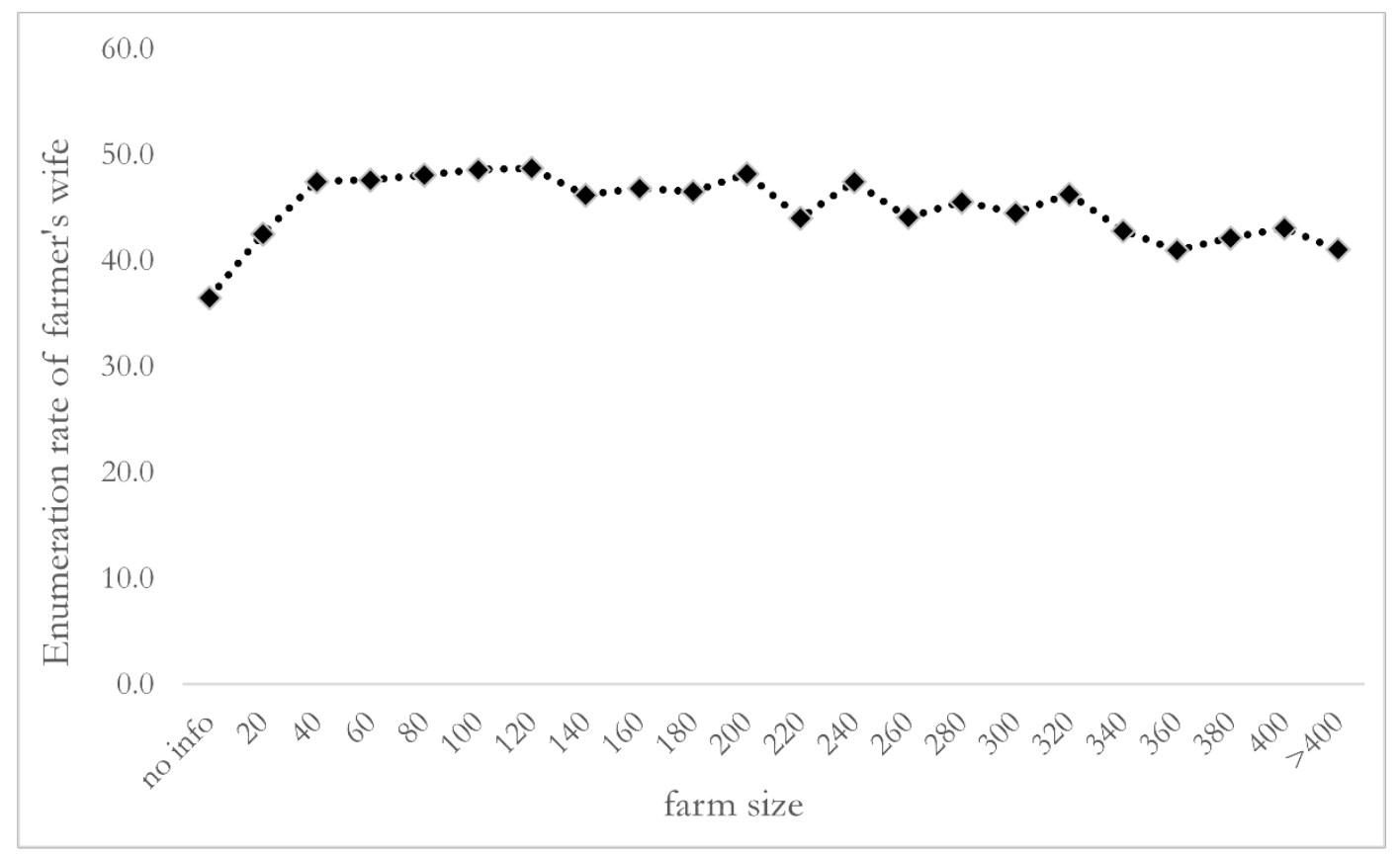

Sources: 1881 CEBs from I-CeM dataset 
Table 1. Number of married women tabulated as 'occupation's wife' in the published census reports and number of married women enumerated as 'occupation's wife' in the CEBs, 1851

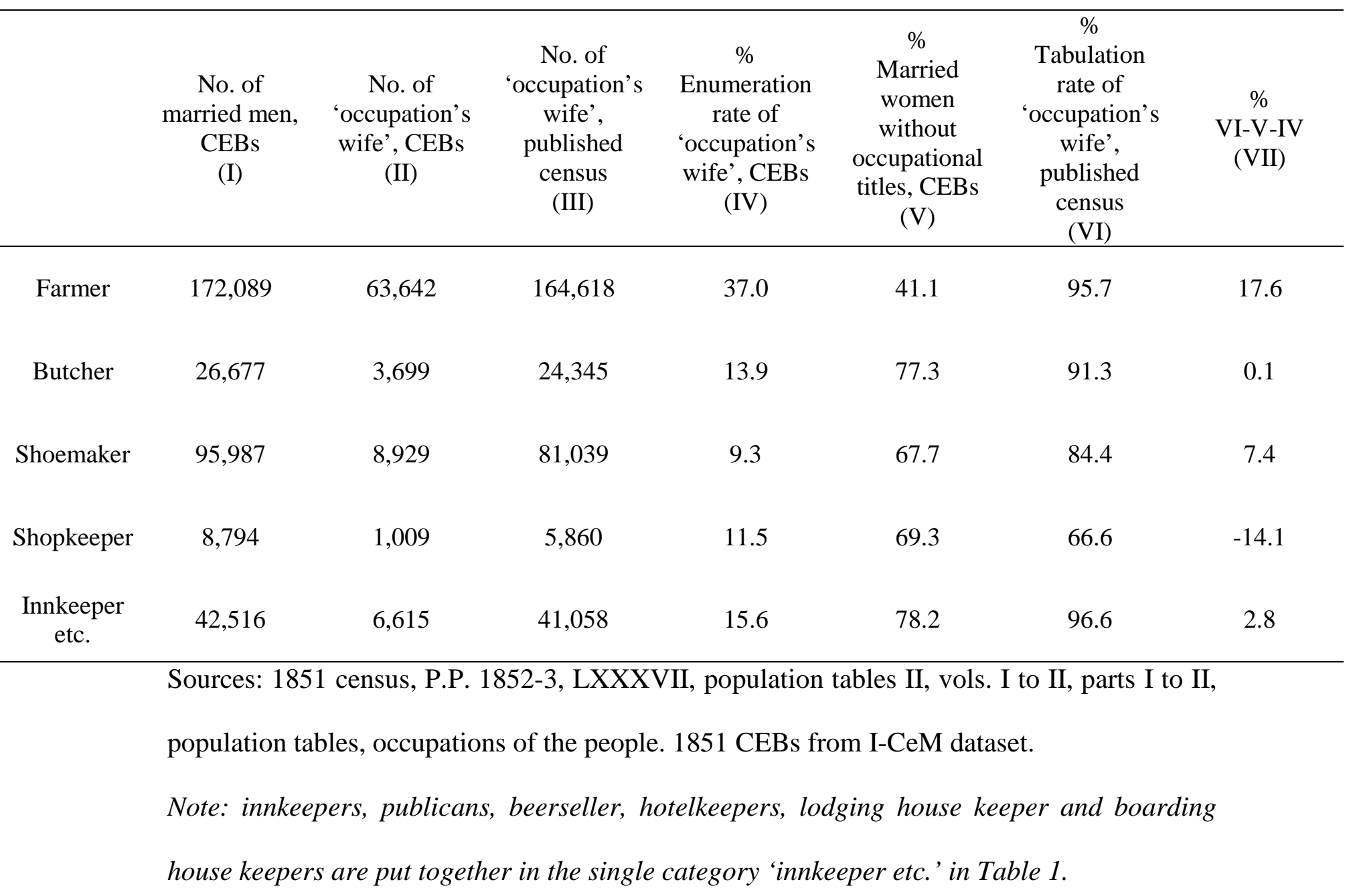


Table 2. Married women enumerated with independent occupational titles and as ‘occupation’s wife’ in the CEBs in England and Wales between 1851 and 1911

\begin{tabular}{|c|c|c|c|c|c|c|c|}
\hline & 1851 & 1861 & 1871 & 1881 & 1891 & 1901 & 1911 \\
\hline $\begin{array}{l}\text { No. of married women with } \\
\text { independent occupational titles }(\alpha)\end{array}$ & 459,737 & 467,040 & - & 505,746 & 429,302 & 384,526 & 542,753 \\
\hline $\begin{array}{l}\text { No. of married women as } \\
\text { 'occupation's wife' }\end{array}$ & 336,891 & 397,113 & - & 560,289 & 14,557 & 15,856 & 76,676 \\
\hline No. of married women & $2,624,525$ & $3,011,604$ & - & $4,080,647$ & $4,481,481$ & $5,171,058$ & $5,975,174$ \\
\hline $\begin{array}{l}\% \text { of married women with } \\
\text { independent occupational titles }\end{array}$ & 17.5 & 15.5 & - & 12.4 & 9.6 & 7.4 & 9.1 \\
\hline $\begin{array}{l}\text { \% of married women as } \\
\text { 'occupation's wife' }\end{array}$ & 12.8 & 13.2 & - & 13.7 & 0.3 & 0.3 & 1.3 \\
\hline
\end{tabular}

Sources: I-CeM dataset

Note $\alpha$ : The top five most common independent occupational titles for married women between 1851 and 1911 in descending order are as follows. The number of married women enumerated with each occupational title is included in the ().

1851: laundry workers $(37,370)$, dressmakers $(33,858)$, domestic servants $(27,149)$, agricultural labourers/farm servants $(16,937)$, and weavers $(15,100)$. 
Table 3. Enumeration rate of 'occupation's wife' by husband's employment sectors and subsectors in England and Wales, 1881

\begin{tabular}{cc}
\hline Husband's occupation & $\begin{array}{c}\text { Proportion of married women } \\
\text { enumerated as 'occupation's } \\
\text { wife', \% }\end{array}$ \\
\hline Primary sector & 21.8 \\
Agriculture & 23.1 \\
Fishing & 17.8 \\
Forestry & 20.2 \\
Mining & 14.6 \\
Other & 23.1 \\
Secondary sector & 10.4 \\
Clothing & 10.8 \\
Earthenware & 9.6 \\
Footwear & 11.1 \\
Building and construction & 11.5 \\
Iron and steel & 10.1 \\
Textiles & 8.3 \\
Other & 10.8 \\
& 12.6 \\
Profession and services & 12.8 \\
Transport & 13.8 \\
Dealer & 13.4 \\
Sector $\quad$ Sourcer & 11.2 \\
\hline
\end{tabular}

Sources: 1881 CEBs from I-CeM dataset 
Table 4. Proportion of married women enumerated as 'occupation's wife' in different types of Enumeration District in England and Wales, 1861

\begin{tabular}{|c|c|c|c|c|c|c|c|c|}
\hline & $\begin{array}{l}\text { No. of } \\
\text { EDs } \\
\text { (I) }\end{array}$ & $\begin{array}{c}\text { No. of } \\
\text { married } \\
\text { women } \\
\text { enumerated } \\
\text { as } \\
\text { ‘occupation's } \\
\text { wife' } \\
\text { (II) } \\
\end{array}$ & $\begin{array}{l}\text { No. of } \\
\text { married } \\
\text { women } \\
\text { (III) }\end{array}$ & $\begin{array}{l}\text { \% of married } \\
\text { women } \\
\text { enumerated as } \\
\text { ‘occupation's } \\
\text { wife' in the ED } \\
\text { (IV) }\end{array}$ & $\begin{array}{l}\% \text { of all } \\
\text { married } \\
\text { women } \\
\text { enumerated as } \\
\text { 'occupation's } \\
\text { wife' in E\&W } \\
\text { (V) }\end{array}$ & $\begin{array}{c}\text { Cumulative \% } \\
\text { of Column V } \\
\text { (VI) }\end{array}$ & $\begin{array}{c}\text { Average } \\
\text { population } \\
\text { size per ED } \\
\text { (VII) }\end{array}$ & $\begin{array}{l}\text { Average No. } \\
\text { of male } \\
\text { occupational } \\
\text { titles per ED } \\
\text { (VIII) }\end{array}$ \\
\hline $\begin{array}{l}\text { All married } \\
\text { women } \\
\text { enumerated as } \\
\text { 'occupation's } \\
\text { wife' }\end{array}$ & 269 & 12,200 & 12,200 & 100.0 & 3.1 & 3.1 & 258.5 & 16.2 \\
\hline $\begin{array}{c}>=90 \text { and }<100 \% \\
\text { of married } \\
\text { women } \\
\text { enumerated as } \\
\text { 'occupation's } \\
\text { wife' }\end{array}$ & 1,185 & 79,118 & 83,728 & 94.5 & 20.1 & 23.2 & 457.2 & 28.5 \\
\hline $\begin{array}{c}>=75 \text { and }<90 \% \\
\text { of married } \\
\text { women } \\
\text { enumerated as } \\
\text { 'occupation's } \\
\text { wife' }\end{array}$ & 1,239 & 76,867 & 92,403 & 83.2 & 19.5 & 42.7 & 494.1 & 34 \\
\hline $\begin{array}{c}>=50 \text { and }<75 \% \\
\text { of married } \\
\text { women } \\
\text { enumerated as } \\
\text { 'occupation's } \\
\text { wife' }\end{array}$ & 1,519 & 77,668 & 125,044 & 62.1 & 19.7 & 62.4 & 547 & 38.1 \\
\hline $\begin{array}{l}>0 \text { and }<50 \% \text { of } \\
\text { married women } \\
\text { enumerated as } \\
\text { 'occupation's } \\
\text { wife' }\end{array}$ & 14,246 & 147,861 & $1,657,949$ & 8.9 & 37.6 & 100.0 & 753.5 & 50.2 \\
\hline $\begin{array}{l}\text { Any married } \\
\text { women } \\
\text { enumerated as } \\
\text { 'occupation's } \\
\text { wife' }\end{array}$ & 18,458 & 393,714 & $1,971,324$ & 20.0 & 100.0 & - & 692.3 & 46.2 \\
\hline $\begin{array}{l}\text { No married } \\
\text { women } \\
\text { enumerated as } \\
\text { 'occupation's } \\
\text { wife' } \\
\end{array}$ & 10,126 & 0.0 & $1,041,382$ & 0.0 & 0.0 & - & 665.9 & 49.3 \\
\hline $\begin{array}{l}\text { All Enumeration } \\
\text { District }\end{array}$ & 28,584 & 393,714 & $3,012,706$ & 13.1 & 100.0 & - & 682 & 47.3 \\
\hline
\end{tabular}


Table 5. Married men's occupational structure in different types of Enumeration Districts distinguished by the enumeration of ‘occupation's wife' in England and Wales, 1861

\begin{tabular}{|c|c|c|}
\hline & $\begin{array}{l}\text { EDs with enumeration of } \\
\text { 'occupation's wife' }\end{array}$ & $\begin{array}{l}\text { EDs with no enumeration } \\
\text { of 'occupation's wife' }\end{array}$ \\
\hline & \multicolumn{2}{|c|}{$\%$ of married men’s employment } \\
\hline Primary & 35.1 & 27.2 \\
\hline Agriculture & 28.3 & 20.6 \\
\hline Mining & 5.9 & 5.8 \\
\hline Other & 0.9 & 0.8 \\
\hline Secondary & 39.3 & 43.5 \\
\hline Clothing & 3.0 & 3.1 \\
\hline Footwear & 3.8 & 3.9 \\
\hline Textiles & 5.8 & 6.0 \\
\hline Iron and steel & 3.4 & 4.0 \\
\hline Machine and tools & 2.2 & 3.2 \\
\hline Building and construction & 8.7 & 9.0 \\
\hline rest & 12.4 & 14.4 \\
\hline Tertiary & 25.6 & 29.3 \\
\hline Dealer and seller & 6.8 & 7.4 \\
\hline Service and professions & 9.6 & 11.1 \\
\hline Transport & 9.1 & 10.8 \\
\hline
\end{tabular}

Sources: 1861 CEBs from I-CeM dataset 
Table 6. Proportion of women who were married to farmers and enumerated as 'farmer's wife' in different type of Enumeration District in England and Wales, 1881

\begin{tabular}{|c|c|c|c|c|c|c|}
\hline & $\begin{array}{l}\text { No. of } \\
\text { EDs } \\
\text { (I) }\end{array}$ & $\begin{array}{l}\text { No. of married } \\
\text { women } \\
\text { enumerated as } \\
\text { 'farmer's wife' } \\
\text { (II) } \\
\end{array}$ & $\begin{array}{l}\text { No. of } \\
\text { women } \\
\text { married to } \\
\text { farmer } \\
\text { (III) } \\
\end{array}$ & $\begin{array}{c}\text { 'farmer's wife' as \% } \\
\text { of women married to } \\
\text { farmer in the ED } \\
\text { (IV) }\end{array}$ & $\begin{array}{c}\text { \% of all married } \\
\text { women enumerated } \\
\text { as 'farmer's wife' } \\
\text { in E\&W } \\
(\mathrm{V})\end{array}$ & $\begin{array}{c}\text { Cumulative \% } \\
\text { of Column V } \\
\text { (VI) }\end{array}$ \\
\hline $\begin{array}{l}\text { All enumerated as 'farmer’s } \\
\text { wife' }\end{array}$ & 3,537 & 24,737 & 24,737 & 100 & 40.1 & 40.1 \\
\hline $\begin{array}{c}>=90 \text { and }<100 \% \text { enumerated } \\
\text { as 'farmer's wife' }\end{array}$ & 560 & 8,837 & 9,468 & 93.3 & 14.3 & 54.4 \\
\hline $\begin{array}{c}>=75 \text { and }<90 \% \text { enumerated as } \\
\text { 'farmer's wife' }\end{array}$ & 1,328 & 11,039 & 13,386 & 82.5 & 17.9 & 72.3 \\
\hline $\begin{array}{c}>=50 \text { and }<75 \% \text { enumerated as } \\
\text { 'farmer's wife' }\end{array}$ & 1,925 & 9,498 & 15,641 & 60.7 & 15.4 & 87.7 \\
\hline $\begin{array}{c}>0 \text { and }<50 \% \text { enumerated as } \\
\text { 'farmer's wife' }\end{array}$ & 3,068 & 7,603 & 34,656 & 21.9 & 12.3 & 100 \\
\hline $\begin{array}{l}\text { Any women enumerated as } \\
\text { 'farmer's wife' }\end{array}$ & 10,418 & 61,714 & 97,888 & 63.0 & 100 & - \\
\hline $\begin{array}{l}\text { No women enumerated as } \\
\text { 'farmer's wife' }\end{array}$ & 10,147 & 0 & 56,769 & 0 & 0 & - \\
\hline $\begin{array}{l}\text { All EDs with married male } \\
\text { farmer }\end{array}$ & 20,565 & 61,714 & 154,657 & 39.9 & 100 & - \\
\hline
\end{tabular}

Sources: 1881 CEBs in I-CeM dataset 
Table 7. Husband and wife's occupations in one Enumeration District in the parish of Owthorne in Yorkshire, 1861

\begin{tabular}{ccc}
\hline Record ID & Husband's occupation & Wife's occupation \\
\hline 1 & TAILOR & TAILOR WIFE \\
2 & JOINER AND FARMER & JOINER WIFE \\
3 & COTTON HAND LOOM WEAVER & SILK FUDEN \\
4 & COTTON PICER & COTTON PICER \\
6 & HAND LOOM WORSLED WEAVER & COTTON THRATE SPINNER \\
7 & COTTON HAND LOOM WEAVER & COTTON HAND LOOM WEAVER \\
8 & JOINER & SHOP KEEPER \\
9 & COTTON MUCE SPINNER & COTTON MUBLER FROM TESLER \\
10 & PULASTERES & \\
\hline
\end{tabular}

Sources: 1861 CEBs from I-CeM dataset 